\title{
Analisis Model Jaringan Sosial Rantai Pemasaran Telur Ayam Ras di Yogyakarta
}

\author{
Analysis of Social Network Model in Marketing Chain of Chicken Egg in Yogyakarta
}

\author{
K. R. Purba, S. P. Syahlani, F. T. Haryadi, S. Andarwati, dan A. R. S. Putra* \\ Departemen Sosial Ekonomi, Fakultas Peternakan, Universitas Gadjah Mada, \\ Jl. Fauna 3, Bulaksumur, Yogyakarta, 55281 \\ *Email: ahmadromadhoni@ugm.ac.id
}

\begin{abstract}
This study aimed to identify social network model on egg marketing chain. The data collection process was conducted from October to November 2017 in Triwidadi Village, Pajangan District, Bantul Regency, Yogyakarta, as one of the center areas of chicken egg agribussiness. Informants of this research were purposively selected from laying chicken breeders and become retailers who have more than a year experience. Data analysis was adopted the descriptive qualitative method. The results showed that emotional based network was the dominant motive to form the network in the marketing chain. The social network between the breeder and the retailer was formed based on kindship, friendship and neighborhood. This created the high social relationships, trust, awareness, control, and cooperation within the marketing chain of chicken eggs in Triwidadi Village. This condition led a homogeneous nature that created more trust to increase the efficiency of transaction costs. Trust caused the egg marketing chain mechanism was easily flowed to market and costumers.
\end{abstract}

Key words: social network, marketing chain, chicken egg, trust

\begin{abstract}
ABSTRAK
Penelitian ini bertujuan untuk mengidentifikasi model jaringan sosial pada rantai pemasaran telur. Penelitian dilakukan pada bulan Oktober sampai dengan November 2017 di Desa Triwidadi, Pajangan, Bantul, Yogyakarta sebagai salah satu pusat agribisinis telur ayam ras. Informan yang terlibat dalam penelitian ini dipilih secara purposif dari para peternak ayam petelur dan pedagang perantara yang telah memiliki pengalaman lebih dari satu tahun. Analisis data menggunakan metode deskriptif kualitatif. Hasil penelitian menunjukkan bahwa jaringan emosi (sentiment) yang lebih dominan untuk membentuk jaringan di rantai pemasaran.Kedekatan antara peternak dengan pedagang perantara terbentuk oleh hubungan kekerabatan, pertemanan dan ketetanggaan. Hal ini membentuk hubungan sosial, kepercayaan, kepedulian, kontrol, dan kerjasama yang terjalin kuat antar pelaku pemasaran telur ayam di Desa Triwidadi. Kondisi ini mengarah kepada homogenisasi sehingga tericipta tingkat kepercayaan (trust) untuk meningkatkan efisiensi biaya transaksi. Kepercayaan yang tinggi menyebabkan mekanisme pemasaran telur dapat berjalan dengan baik untuk memasok pasar maupun konsumen.
\end{abstract}

Kata kunci: jaringan sosial, rantai pemasaran, telur ayam ras, kepercayaan

\section{PENDAHULUAN}

Pembangunan peternakan diarahkan untuk memenuhi protein hewani serta menciptakan lapangan kerja bagi masyarakat (Mamilianti, 2012). Salah satu usaha yang dilakukan yaitu pengembangan usaha peternakan ayam petelur yang bertujuan menghasilkan telur untuk pemenuhan kebutuhan protein hewani. Prospek usaha peternakan ayam ras petelur di Indonesia dinilai sangat baik ditinjau dari sisi penawaran dan permintaan di pasar baik di dalam dan di luar negeri. Saat ini produksi telur ayam masih belum mencapai kapasitas produksi yang sesungguhnya (Abidin, 2003). Artinya, prospek pengembangannya masih terbuka. Produksi telur ayam ras saat ini baru mencukupi kebutuhan pasar dalam negeri sebesar $65 \%$. Sisanya dipenuhi dari telur ayam kampung, itik, dan puyuh. (Pusat Data dan Sistem Informasi Pertanian, 2016).

Salah satu upaya pengembangan komoditas peternakan ayam petelur secara 
umum adalah usaha dalam menciptakan kondisi pasar ideal. Kondisi pasar ideal adalah pasar persaingan sempurna yang akan dapat menjamin berlangsungnya aktivitas produksi dengan tingkat efisiensi yang tinggi yang dilakukan baik dari harga, distribusi, dan daya tawar (Kardono dan Hanani, 2004). Untuk itu sistem pemasaran perlu didesain dalam kerangka untuk memperluas pasar, mendorong akses tentang informasi pasar, meningkatkan perlindungan konsumen, dan meningkatkan sarana dan prasarana pemasaran.

Pemasaran adalah suatu proses sosial yang melibatkan kegiatan-kegiatan penting yang memungkinkan individu dan perusahaan mendapatkan apa yang mereka butuhkan dan inginkan melalui pertukaran dengan pihak lain untuk mengembangkan hubungan pertukaran (Boyd et al., 2000). Dalam sistem pemasaran, jaringan sosial menjadi penting karena peternak memerlukan bantuan orang yang berada di luar komunitasnya (Vissa, 2012). Pada dasarnya, jaringan sosial terbentuk karena adanya rasa saling tahu, saling menginformasikan, saling mengingatkan, dan saling membantu dalam melaksanakan ataupun mengatasi sesuatu (Lawang, 2005).

Kolaborasi horizontal yang melibatkan peternak seringkali memiliki konfigurasi yang terfokus pada hubungan sosial untuk aktivitas jual beli (McAdam et al., 2016). Hubungan sosial yang membentuk jaringan sosial terdiri dari tiga macam yaitu: (1) jaringan kekuasaan (power) yaitu hubungan sosial yang bermuatan kekuasaan; (2) jaringan kepentingan (interest) yaitu hubungan sosial yang bermakna pada tujuantujuan khusus; dan (3) Jaringan perasaan (sentiment), terbentuk atas dasar hubungan sosial yang bermuatan perasaan (Agusyanto, 2007). Dalam konteks sistem pemasaran telur maka perlu dikaji manfaat dari jaringan sosial di dalam rantai pemasaran telur untuk melihat peran jaringan sosial tersebut dalam memasok kebutuhan telur di pasar. Sementara itu, jaringan sosial sendiri menyediakan potensi yang signifikan untuk mendorong pertumbuhan pembangunan di pedesaan (Brink, 2011). Penelitian ini bertujuan untuk mengidentifikasi model jaringan sosial pada rantai pemasaran telur sekaligus mengidentifikasi faktor-faktor pendorong terbentuknya jaringan sosial tersebut.

\section{MATERI DAN METODE}

Penelitian dilakukan pada bulan Oktober sampai dengan November 2017, di Desa Triwidadi, Kecamatan Pajangan, Kabupaten Bantul, Propinsi D. I. Yogyakarta. Materi yang digunakan dalam penelitian ini adalah informan yang terdiri dari peternak ayam petelur dan pedagang perantara. Metode pengumpulan data yang dipergunakan dalam penelitian ini adalah wawancara. Informan yang dipilih ditentukan dengan purposive. Kriteria yang ditentukan dalam pemilihan informan yaitu: peternak yang sudah beternak lebih dari 1 tahun dan mengetahui tentang pemasaran telur ayam ras. Metode triangulasi diterapkan untuk menjamin validitas dan reliabilitas informasi dari para peternak maupun pedagang perantara. Data yang terkumpul dianalisis secara deskriptif kualitatif.

\section{HASIL DAN PEMBAHASAN}

Gambaran umum mengenai umur dari informan dalam penelitian ini disajikan dalam Tabel 1. Persentase terbesar umur informan berada pada umur 38-47 tahun yaitu sebesar 43,33 \% dengan jumlah informan 13 orang, sedangkan persentase yang paling sedikit berada pada umur 58-67 tahun yaitu sebesar 3,33\% dengan jumlah informan satu orang, sehingga didapatan rata-rata umur sebesar 43,76 \pm 9,12 tahun. Arsyad (1999), menyatakan bahwa umur 15 sampai 64 tahun termasuk orang-orang dalam umur kerja. Dari hasil penelitian diperoleh bahwa peternak secara keseluruhan masih dalam kategori usia produktif. Berdasarkan umur, maka peternak tersebut sangat berpotensi mengembangkan usaha ternak ayam petelur. Hal ini sesuai dengan pendapat Hernanto (1996) yang menyatakan bahwa usia produktif sangat penting bagi 
pelaksanaan usaha karena usia ini peternak mampu mengkoordinasi dan mengambil langkah yang efektif.

Tabel 1. Klasifikasi informan berdasarkan umur

\begin{tabular}{ccc}
\hline $\begin{array}{c}\text { Umur } \\
\text { (tahun) }\end{array}$ & $\begin{array}{c}\text { Jumlah } \\
\text { (orang) }\end{array}$ & $\begin{array}{c}\text { Persentase } \\
(\%)\end{array}$ \\
\hline $28-37$ & 7 & 23,33 \\
$38-47$ & 13 & 43,33 \\
$48-57$ & 9 & 30,00 \\
$58-67$ & 1 & 3,33 \\
\hline Total & 30 & 100,00 \\
\hline \multicolumn{4}{l}{ Rata-rata } & $43,76 \pm 9,12$ tahun \\
\hline \multicolumn{4}{l}{ Sumber: Data primer terolah $(2017)$}
\end{tabular}

Hampir keseluruhan informan berjenis kelamin laki-laki. Dari total 30 peternak, terdapat tiga orang peternak yang memiliki jenis kelamin perempuan. Banyaknya jumlah laki-laki menunjukkan bahwa dalam melakukan usaha peternakan kebanyakan dilakukan oleh laki-laki, namun tidak menutup kemungkinan bagi kaum perempuan juga mampu melakukannya.

Selanjutnya, tingkat pendidikan yang disajikan pada Tabel 2 menunjukkan bahwa tingkat pendidikan peternak sebagian besar adalah SD yaitu berjumlah 18 orang $(60,00 \%)$, disusul dengan tingkat pendidikan SMA yaitu berjumlah 7 orang $(23,33 \%)$. Data ini menunjukkan bahwa sebagian peternak di Desa Triwidadi belum menempuh pendidikan dasar 9 tahun.

Tabel 2. Klasifikasi informan berdasarkan tingkat pendidikan

\begin{tabular}{lcc}
\hline $\begin{array}{l}\text { Tingkat } \\
\text { pendidikan }\end{array}$ & $\begin{array}{c}\text { Jumlah } \\
\text { (orang) }\end{array}$ & $\begin{array}{c}\text { Persentase } \\
(\%)\end{array}$ \\
\hline SD & 18 & 60,00 \\
SMP & 3 & 10,00 \\
SMA & 7 & 23,33 \\
Strata 1 & 2 & 6,67 \\
\hline Total & 30 & 100,00 \\
\hline
\end{tabular}

Sumber: Data primer terolah (2017)

Tinggi rendahnya tingkat pendidikan yang dimiliki oleh informan berpengaruh terhadap tingkat kemampuan dan cara berfikir yang mereka miliki yang berimplikasi terhadap kemampuan peternak dalam penerapan teknologi.

Pengalaman beternak merupakan lama waktu yang telah dilalui oleh peternak dalam menjalankan suatu usaha. Pengalaman beternak merupakan faktor penting yang harus dimiliki oleh seorang peternak untuk memutuskan segala kebijakan yang akan diterapkan dalam usahanya (Tabel 3). Hasil penelitian menyatakan bahwa pengalaman beternak 1-5 tahun adalah yang terbesar dengan jumlah delapan orang dengan persentase sebesar $26,67 \%$, kemudian disusul dengan jarak pengalaman beternak 16-20 tahun berjumlah tujuh orang dengan persentase $23,33 \%$. Didapatkan rata-rata pengalaman beternak yaitu 12,46 $\pm 8,52$ tahun. Mastuti dan Hidayat (2008) menyatakan bahwa, semakin lama beternak diharapkan pengetahuan yang didapat semakin banyak sehingga keterampilan dalam menjalankan usaha peternakan semakin meningkat.

Tabel 3. Klasifikasi informan berdasarkan pengalaman beternak

\begin{tabular}{lcr}
\hline $\begin{array}{l}\text { Pengalaman } \\
\text { beternak (tahun) }\end{array}$ & $\begin{array}{r}\text { Jumlah } \\
\text { (orang) }\end{array}$ & $\begin{array}{r}\text { Persentase } \\
(\%)\end{array}$ \\
\hline $1-5$ & 8 & 26,67 \\
$6-10$ & 6 & 20,00 \\
$11-15$ & 6 & 20,00 \\
$16-20$ & 7 & 23,33 \\
$21-35$ & 3 & 10,00 \\
\hline Total & 30 & 100,00 \\
\hline Rata-rata & $12,46 \pm 8,52$ tahun \\
\hline \multicolumn{4}{l}{ Sumber: Data primer terolah $(2017)$}
\end{tabular}

Kepemilikan ternak menunjukkan banyaknya ayam petelur yang dimiliki oleh informan.Jumlah kepemilikan ternak pada tiap informan berbeda-beda tergantung kondisi usaha.Adapun klasifikasi informan berdasarkan kepemilikan ternak disajikan pada Tabel 4. Sebagian besar jumlah kepemilikan ternak berada di kategori 1.0002.000 ekor yang berjumlah 18 orang dengan persentase $60,00 \%$, sehingga didapatkan rata- 
rata $1.470 \pm 798,33$ ekor. Dapat diketahui bahwa peternakan ayam petelur di Desa Triwidadi masih berskala kecil. Menurut Talib et al. (2007), jumlah kepemilikan ayam yang kurang dari 1.000 ekor hingga 5.000 ekor termasuk peternakan dalam skala kecil.

Tabel 4. Klasifikasi informan berdasarkan kepemilikan ternak

\begin{tabular}{lcc}
\hline $\begin{array}{l}\text { Jumlah } \\
\text { kepemilikan } \\
\text { ternak (ekor) }\end{array}$ & $\begin{array}{c}\text { Jumlah } \\
\text { (orang) }\end{array}$ & $\begin{array}{c}\text { Persentase } \\
(\%)\end{array}$ \\
\hline$<1.000$ & 7 & 23,33 \\
$1.000-2.000$ & 18 & 60,00 \\
$>2.000$ & 5 & 16,67 \\
Total & 30 & 100,00 \\
\hline Rata-rata & $1.470 \pm 798,33$ ekor \\
\hline
\end{tabular}

Sumber : Data primer terolah (2017)

Produksi telur menunjukkan rerata jumlah produksi telur dalam sehari yang dimiliki oleh informan. Jumlah rerata produksi telur pada tiap informan berbedabeda tergantung kondisi usaha. Adapun klasifikasi informan berdasarkan rerata produksi telur per hari dapat dilihat pada Tabel 5. Dari hasil data penelitian menunjukkan bahwa kategori produksi telur kurang dari $50 \mathrm{~kg}$ mempunyai hasil yang berimbang dengan kategori produksi telur 50-100 kg dengan masing-masing jumlah informan 13 orang dan memiliki persentase $43,33 \%$, sedangkan kategori produksi telur yang lebih dari $100 \mathrm{~kg}$ hanya berjumlah empat orang dengan persentase sebesar 13,33\%. Dari data Tabel 5, diperoleh ratarata produksi telur yaitu $59,86 \pm 32,79 \mathrm{~kg}$. Hal ini menunjukkan bahwa skala produksi telur masih dalam skala kecil atau skala peternakan rakyat. Menurut Aziz (1993), peternakan rakyat mempunyai ciri-ciri, yaitu skala usahanya relatif kecil, merupakan usaha rumah tangga, dilakukan sebagai usaha sampingan, menggunakan teknologi sederhana sehingga produktivitas rendah dan mutu produk tidak seragam, serta bersifat padat karya dan basis organisasi kekeluargaan.
Tabel 5. Klasifikasi informan berdasarkan rerata produksi telur per hari

\begin{tabular}{ccc}
\hline $\begin{array}{c}\text { Produksi } \\
\text { telur }(\mathrm{kg})\end{array}$ & $\begin{array}{c}\text { Jumlah } \\
\text { informan } \\
\text { (orang) }\end{array}$ & $\begin{array}{c}\text { Persentase } \\
(\%)\end{array}$ \\
\hline$<50$ & 13 & 43,33 \\
$50-100$ & 13 & 43,33 \\
$>100$ & 4 & 13,33 \\
\hline Total & 30 & 100,00 \\
\hline \multicolumn{2}{l}{ Rata-rata } & $59,86 \pm 32,79 \mathrm{~kg}$ \\
\hline \multicolumn{3}{l}{ Sumber: Data primer terolah (2017) }
\end{tabular}

\section{Model pemasaran telur}

Distribusi adalah kegiatan pemasaran yang berusaha untuk memperlancar dan mempermudah penyampaian barang dan jasa dari produsen ke konsumen sehingga penggunaannya sesuai dengan yang diperlukan seperti jenis, jumlah, harga, tempat dan saat dibutuhkan. Dari hasil wawancara menunjukkan bahwa strategi distribusi peternak ayam petelur yang berada di Desa Triwidadi terdiri dari tiga macam, yaitu:(1) Dijual sendiri yaitu hasil produksi telur langsung di distribusikan peternak ke pasar maupun konsumen akhir; (2) Diambil oleh pedagang perantara yaitu hasil produksi telur langsung diambil oleh pedagang perantara kemudian pedagang perantara tersebut mendistribusikan ke pasar atau konsumen akhir; (3) Dijual sendiri dan diambil oleh pedagang perantara yaitu cara sistem distribusi ini dengan menggabungkan keduanya yang biasanya dipengaruhi oleh faktor waktu.

Tabel 6. Strategi distribusi informan

\begin{tabular}{lcc}
\hline \multicolumn{1}{c}{ Strategi distribusi } & $\begin{array}{c}\text { Jumlah } \\
\text { informan } \\
\text { (orang) }\end{array}$ & $\begin{array}{c}\text { Persentase } \\
(\%)\end{array}$ \\
\hline $\begin{array}{l}\text { Dijual sendiri } \\
\begin{array}{l}\text { Diambil oleh pedagang } \\
\text { perantara }\end{array}\end{array}$ & 5 & 16,67 \\
$\begin{array}{l}\text { Dijual sendiri dan } \\
\text { diambil oleh pedagang } \\
\text { perantara }\end{array}$ & 1 & 80,00 \\
\hline Total & 30 & 100,00 \\
\hline Sumber: Data primer terolah $(2017)$ &
\end{tabular}


Jika peternak mempunyai waktu luang maka hasil produksi telur akandidistribusikan sendiri ke pasar maupun konsumen akhir, tetapi jika peternak tidak mempunyai waktu yang cukup maka membutuhkan pedagang perantara untuk mendistribusikan ke pasar maupun konsumen akhir.

Hasil penelitian menyatakan bahwa sebagian besar strategi distribusi peternak (Tabel 6) untuk mendistribusikan hasil produksi telurnya yaitu diambil oleh pedagang perantara dengan jumlah informan 24 orang dan persentase $80 \%$, kemudian disusul dengan strategi distribusi yang dijual sendiri berjumlah 5 informan dengan persentase $16,67 \%$. Strategi distribusi yang menggabungkan keduanya yaitu diambil oleh pedagang perantara dan dijual sendiri hanya berjumlah satu orang dengan persentase $3,33 \%$. Hal ini menunjukkan bahwa peternak sangat bergantung kepada pedagang perantara untuk mendistribusikan produknya. Seperti yang diungkapkan Bapak Solikin:

"Nggih niku, sulit nggolek pangsa pasar mas. Dadi dipasrahke karo tengkulak nopo bakulbakul niku mas, soale relasi pasar'e luwih apik timbang kulo niki”. (Ya begini Mas, sulit mencari pasar. Jadi diserahkan ke tengkulak atau pedagang perantara yang memiliki hubungan ke pasar lebih baik).

Saluran pemasaran adalah penyaluran barang atau jasa dari produsen ke konsumen akhir, dan yang menyelenggarakannya berupa lembaga atau badan-badan yang bertugas melaksanakan fungsi pemasaran itu sendiri atau memenuhi keinginan konsumen akhir semaksimal mungkin, sedangkan pihak konsumen akhir akan memberikan imbalan berupa margin kepada lembaga pemasaran tersebut. Pemasaran telur yang banyak dipilih oleh para peternak kecil adalah pola pemasaran tidak langsung atau melalui perantara (middleman), dan sedikit yang menjual langsung kepada konsumen akhir. Secara umum proses saluran pemasaran telur dari para peternak kecil di Desa Triwidadi kepada konsumen akhir hanya melibatkan pedagang perantara dan agen (Tabel 7).

Tabel 7 menunjukkan bahwa saluran pemasaran kategori "peternak $\rightarrow$ pedagang perantara $\rightarrow$ konsumen akhir" mempunyai hasil persentase yang paling besar yaitu $56,67 \%$ dengan jumlah informan 17 . Disusul dengan kategori "peternak $\rightarrow$ konsumen akhir" yang mempunyai jumlah informan 10 orang dengan persentase 33,33\%. Terakhir kategori "peternak $\rightarrow$ agen $\rightarrow$ pedagang perantara $\rightarrow$ konsumen akhir" mempunyai jumlah tiga informan dan persentase sebesar $10,00 \%$. Ini menunjukkan bahwa sebagian besar peternak di Desa Triwidadi langsung menjual hasil produksinya kepada pedagang perantara.

Dengan melihat ketiga saluran pemasaran tersebut diatas, maka lembaga pemasaran yang turut serta dalam aktivitas dalam pemasaran ini dapat diklasifikasikan sebagai berikut: Pertama, pedagang perantara merupakan pedagang yang membeli dan menyalurkan sendiri hak milik atas produk telur dan selanjutnya dijual kepada pihak lain. Kedua, agen merupakan lembaga yang melaksanakan perdagangan dengan cara menyediakan jasa-jasa penjualan atau distribusi barang akan tetapi mereka tidak mempunyai wewenang atau hak untuk memiliki barang yang diperdagangkan tersebut.

Tabel 7. Saluran pemasaran informan

Saluran pemasaran

Jumlah

informan Persentase (\%)

(orang)

\begin{tabular}{lcc}
\hline Peternak $\rightarrow$ konsumen akhir & 10 & 33,33 \\
Peternak $\rightarrow$ pedagang perantara $\rightarrow$ konsumen akhir & 17 & 56,67 \\
Peternak $\rightarrow$ agen $\rightarrow$ pedagang perantara $\rightarrow$ konsumen akhir & 3 & 10,00 \\
\hline Total & 30 & 100,00 \\
\hline
\end{tabular}

Sumber: Data primer terolah 2017 


\section{Jaringan sosial pemasaran}

Jaringan sosial terbentuk karena adanya kesamaan dalam produksi dan distribusi sumberdaya yang menyebabkan adanya pihak yang memiliki kekuasaan atau kemampuan untuk mengontrol sumberdaya dan adanya pihak yang dikontrol (Mirajiani et al., 2014). Dari hasil penelitian didapatkan beberapa tingkat hubungan atau jaringan sosial antara peternak dengan pedagang perantara, yaitu: (1) Hubungan kekerabatan: hubungan yang memiliki asal usul silsilah yang sama, baik melalui keturunan biologis, sosial, maupun budaya; (2) Sudah berlangganan: hubungan yang didasari dengan kerja sama serta mempunyai visi misi yang sama antara peternak dengan pedagang perantara sehingga terbentuk kebiasaan yang terus-menerus terulang dan akhirnya menciptakan ikatan emosional diantara peternak dan pedagang perantara; (3) Sudah mempunyai pasar: hubungan yang didasari karena pedagang perantara tersebut sudah mempunyai pasar untuk menjualkan dan mendistribusikan telur ke konsumen akhir.

Tabel 8. Jaringan sosial informan

\begin{tabular}{lcc}
\hline Jaringan sosial & $\begin{array}{c}\text { Jumlah } \\
\text { informan } \\
\text { (orang) }\end{array}$ & $\begin{array}{c}\text { Persentase } \\
(\%)\end{array}$ \\
\hline Hubungan kekerabatan & 14 & 46,67 \\
Sudah berlangganan & 13 & 43,33 \\
Sudah mempunyai & 3 & 10,00 \\
pasar & & \\
\hline Total & 30 & 100,00 \\
\hline
\end{tabular}

Sumber: Data primer terolah 2017

Tabel 8 menunjukkan bahwa sebagian besar terbentuknya jaringan sosial antara peternak dengan pedagang perantara yang ada di Desa Triwidadi karena adanya hubungan kekerabatan.Jaringan sosial karena hubungan kekerabatan terdiri dari 14 orang dengan persentase $46,67 \%$, kemudian disusul dengan jaringan sosial karena sudah berlangganan yang mempunyai jumlah informan 13 orang dan persentase $43,33 \%$, dan yang terakhir jaringan sosial karena sudah mempunyai pasar mempunyai jumlah informan 3 orang dengan persentase $10,00 \%$.
Hal ini menunjukkan bahwa jaringan sosial antara peternak dengan pedagang dikategorikan jaringan sentiment (jaringan emosi), dimana jaringan yang terbentuk atas dasar hubungan sosial yang bermuatan emosi.Hal itu disebabkan kedekatan antara peternak dengan pedagang perantara disebabkan oleh hubungan kekerabatan, pertemanan dan ketetanggaan. Seperti penuturan Ibu Ngatijem berikut ini:

"Yo karang mpun berlangganan dan juga Pak Jiman niku pak lik kulo, dadi nggih yo wonten hubungan kerabat juga mas". (Ya sudah terlanjur berlangganan dan juga Pak Jiman itu Paman saya, jadi masih ada hubungan keluarga)

Menurut Agusyanto (2007), jaringan sosial merupakan suatu jaringan tipe khusus dimana 'ikatan' yang menghubungkan satu titik ke titik lain di dalamnya ialah hubungan sosial. Dalam hal ini, hubungan sosial diikat oleh adanya unsur kepercayaan yang mana kepercayaan itu dipertahankan oleh adanya norma-norma yang ada. Seperti penuturan Bapak Sutarno berikut ini:

"Alasanipun kulo diambil pedagang niku sudah partner lama mas, istilahnya sudah join gitu, saling percaya".(Alasan saya diambil pedangang yak arena sudah partner lama Mas, istilahnya sudah join, saling percaya)

Pada konsep jaringan sosial terdapat unsur kerja yang melalui hubungan sosial yakni kerja sama. Seperti yang diungkapkan Bapak Hermawan berikut:

"Ya, jadi lebih tahu harga pasar kan lebih cepet, lebih cepet juga kalau jual sendiri. Kalau kendalanya diambil sama bakul, istilahnya itu lho kalau harga murah dia kesulitan menjual. Jadi numpuk stok telur disini, padahal kan produksi kan harus butuh sirkulasi uangnya harus cepet karena tiap minggu kan harus beli pakan. Itu kadang kalau pas harga jual murah, itu kesulitan jual telur jadi sampai numpuk-numpuk”. (Ya, jadi lebih tahu harga pasar kan lebih cepat, lebih cepat juga kalau jual sendiri. Kalau kendalanya diambil pedagang, istilahnya itu kalau harga murah, dia kesulitan menjual. Jadi numpuk stok telur di sini, padahal 
produksi harus butuh sirkulasi uang yang cepat karena tiap minggu harus beli pakan. Itu kadang kalau pas harga jual murah, kesulitan jual telur, jadi sampai bertumpuktumpuk)

Jaringan emosi terbentuk atas hubungan-hubungan sosial, dimana hubungan sosial itu sendiri menjadi tujuan tindakan sosial misalnya dalam pertemanan, percintaan atau hubungan kerabat dan sejenisnya. Jaringan sosial yang dibentuk oleh hubungan-hubungan emosi ini cenderung lebih mantap dan permanen, maka muncul sebagai konsekuensi, suatu mekanisme yang fungsinya menjamin stabilitas struktur yang ada sehingga hubungan-hubungan sosial semacam ini bisa dinilai semacam norma-norma yang dapat membatasi suatu tindakan sosial yang cenderung mengganggu kepermanenan struktrur jaringan tersebut (Agusyanto, 2007). Jaringan antara peternak dan pedagang perantara juga berpengaruh besar terhadap kelangsungan usaha dagang telur karena pasokan barang akan mudah didapat jika telah terjalin komunikasi dan saling mengenal antara pedagang perantara. Interaksi yang terus berlangsung itu pada akhirnya akan terbentuk suatu pola hubungan yang tetap yaitu berupa jaringan sosial yang secara tidak disadari hal itu merupakan sebagai suatu strategi mereka untuk tetap survive di komunitas lingkungan sekitarnya. Jaringan sosial merupkan salah satu cara untuk mengidentifikasi potensi dan kesempatan dalam mengembangkan usaha bagi peternak (Stam et al., 2014). Di sisi lain, interaksi itu juga dapat menimbulkan ikatanikatan emosional antara peternak dengan pedagang perantara sehingga membentuk rasa saling percaya atau trust.

Kepercayaan memiliki dampak positif terhadap efisiensi biaya-biaya transaksi, artinya antara pedagang dan pedagang perantara telah memiliki kepercayaan (saling mempercayai) satu sama lain. Adanya rasa kepercayaan akan membuat transaksi jual beli terus berjalan sekalipun telah terjadi perjanjian hutang-piutang dalam transaksi ekonomi tersebut. Hasbullah (2006) membagi tiga tingkatan trust yaitu pada tingkatan individual, relasi sosial dan pada tingkatan personal dan sekaligus sebagai karakteristik individu. Pada tingkatan hubungan sosial, trust merupakan atribut kolektif untuk mencapai tujuan-tujuan kelompok. Sedangkan pada tingkatan sistem sosial trust merupakan nilai yang berkembang menurut sistem sosial yang ada. Trust juga dipandang sebagai komponen ekonomi yang relevan pada kultur yang ada pada masyarakat dan membentuk kekayaan modal sosial sebagai salah satu indikator dari kesejahteraan bagi rumah tangga peternak (Putra et al., 2017).

\section{KESIMPULAN}

Diantara ketiga jaringan sosial seperti jaringan kekuasaan, kepentingan dan emosi, hasil penelitian menunjukkan bahwa jaringan emosi (sentiment) yang lebih kuat dibandingkan jaringan interest dan jaringan power. Hal itu disebabkan karena kedekatan antara peternak dengan pedagang perantara dipengaruhi oleh hubungan kekerabatan, pertemanan dan ketetanggaan. Dominasi jaringan sentiment (emosi) yang terbentuk mengakibatkan tingginya hubungan sosial, kepercayaan, kepedulian, kontrol, dan kerjasama yang terjalin antar pelaku pemasaran telur ayam di Desa Triwidadi.

\section{DAFTAR PUSTAKA}

Abidin, Z. 2003. Meningkatkan produktifitas ayam petelur. PT. Agromedia. Jakarta.

Agusyanto, R. 2007. Jaringan sosial dalam organisasi. Rajawali Pers: Jakarta.

Arsyad, L. 1999. Pengantar perencanaan dan pembangunan ekonomi daerah, Edisi Pertama, BPFE.Yogyakarta.

Aziz, M. A. 1993. Agroindustri buah-buahan tropis prospek pengembangan pada PJPT II. Penerbit Bangkit: Jakarta.

Boyd, H. W., O. C. Walker, dan J. C. Larreche. 2000. Manajemen pemasaran: suatu pendekatan strategis 
dengan orientasi global. Edisi Bahasa Indonesia. Jakarta: Erlangga.

Brink, T. 2011. What connections in networks of private entrepreneurs are related to growth?. Ager: Revista de estudios sobre despoblación y desarrollo rural $=$ Journal of depopulation and rural development studies. 11: 57-82.

Hasbullah, J. 2006. Sosial Kapital: Menuju Keunggulan Budaya Manusia Indonesia. MR-United Press: Jakarta.

Hernanto, F. 1996. Ilmu Usaha Tani. Penebar Swadaya. Jakarta.

Kardono dan N. Hanani. 2004. Teori Ekonomi Makro: Pendekatan Grafis dan Matematis. Fakultas Ekonomi Universitas Brawijaya. Malang.

Lawang, R. M. Z. 2005. Kapital sosial dalam perspektif sosiologi. Cetakan Kedua. Fakultas Ilmu Sosial dan Ilmu Politik Universitas Indonesia Press: Depok.

Mamilianti, W. 2012. Kajian pemasaran telur ayam di kecamatan sukorejo kabupaten pasuruan. Agromix. 1(1) : 75-86

Mastuti, S., dan N. N. Hidayat. 2009. Peranan tenaga kerja perempuan dalam usaha ternak sapi perah di Kabupaten Banyumas. JAP. 11(1): 40-47.

McAdam, M., R. McAdam, A. Dunn, and C. McCall. 2016. Regional horizontal networks within the SME agri-food sector: An innovation and social network perspective. Regional Studies. 50(8) : 1316-1329.

Mirajiani, E. S. Wahyuni, A. Satria, Saharuddin dan T. Kusumastanto. 2014. Transformasi pranata patronase masyarakat nelayan: dari ekonomi moralitas menuju ekonomi pasar. Jurnal Komunitas: Research \& Learning in Sociology and Anthropology. 6(1):115-134

Pusat Data dan Sistem Informasi Pertanian. 2016. "Outlook Telur". Komoditas Pertanian Subsektor Peternakan". ISSN 1907-1507. Sekretariat Jenderal Kementerian Pertanian. Jakarta.

Putra, R. A. R. S., B. Ariyadi, N. Kurniawati, dan F. T. Haryadi. 2017. Pengaruh modal sosial terhadap tingkat kesejahteraan rumah tangga peternak: studi kasus pada kelompok peternak ayam kampung Ngudi Mulyo, Gunungkidul. Buletin Peternakan. 41(3): 349-354.

Stam, W., S. Arzlanian, and T. Elfring. 2014. Social capital of entrepreneurs and small firm $p$ erformance: A metaanalysis of contextual and methodological moderators. Journal of Business Venturing. 291: 152-173.

Talib, C., A. Bamualim, dan I. Inounu. 2007. Restrukturisasi Peternakan di Indonesia. Pusat Penelitian dan Pengembangan Peternakan. Bogor

Vissa, B. (2012). Agency in action: Entrepreneurs' networking style and initiation of economic exchange. Organization Science. 23(2): 492-510. 